Article

\title{
Investigating the Links of Interpersonal Trust in Telecommunications Companies
}

\author{
Helena Bulińska-Stangrecka ${ }^{1, *}$ (DD and Anna Bagieńska ${ }^{2}$ \\ 1 Faculty of Administration and Social Sciences, Warsaw University of Technology, 1 Plac Politechniki Street, \\ 00-661 Warszawa, Poland \\ 2 Faculty of Engineering Management, Bialystok University of Technology, 45A Wiejska Street, \\ 15-351 Bialystok, Poland; a.bagienska@pb.edu.pl \\ * Correspondence: h.bulinska-stangrecka@ans.pw.edu.pl; Tel.: +48-504-317-811
}

Received: 31 May 2018; Accepted: 19 July 2018; Published: 20 July 2018 updates

\begin{abstract}
The purpose of this paper is to determine if there are links between interpersonal trust and competences, relations, and cooperation in Polish telecommunications companies. It examines which factors affect trust in co-workers and managers in sustainable organizations. The paper surveys a sample of 175 employees of telecommunications companies in Poland by means of a questionnaire. The results indicate that competences, relations, and cooperation are related to interpersonal trust. Regression analysis showed that competences and relations predict a significant variance in trust amongst co-workers. Additionally, cooperation contributes to prediction of trust in managers. Given the importance of trust in sustainable organizations, better comprehension of which factors are related to team confidence provides valuable information for stakeholders and about how to improve interpersonal trust in sustainable organizations.
\end{abstract}

Keywords: interpersonal trust; sustainable organizations; competences; relations; cooperation

\section{Introduction}

Contemporary companies which aspire to be sustainable in the long term should not only make sure they turn a profit but should also implement a sustainable development strategy and be socially responsible. The sustainable activity of organizations arises from the needs and expectations of both the external environment and the internal stakeholders. However, above all it is the result of the appropriate management and involvement of all staff and managers. Research demonstrates that companies' sustainability strategies are not motivated by public relations, but that such strategies reflect "substantive changes in business processes" [1,2]. Sustainability is a management concept of successful contemporary organizations because it facilitates flexibility in adapting to constantly changing environmental conditions and it even helps companies operate in times of crisis and chaos.

Sustainability is considered to be a crucial challenge for organizations seeking a competitive advantage, but also for organizations facing other kinds of problems, such as talent retention. $70 \%$ perceive sustainability as a key element in their management programs [3]. Organizations which include in their strategies practices and activities that are in line with the idea of sustainability are called sustainable enterprises [1,4-6]. What distinguishes a sustainable enterprise is, among others, the fact that its dominating capital is social capital that is based on good relationships between itself and its external and internal environments, including its employees. Building social capital is based principally on trust and thus it is emphasized that this is one of the main components of sustainable enterprises [7].

Trust is one of the crucial conditions of sustainable management [8]. Many scholars allude to the fact that organizational trust is a crucial element of successful cooperation [9-12]. Organizational 
trust impacts various areas of management: communication [13], negotiation [14], leadership [15], and work performance [16]. Subsequently, it is an important factor that supports the functioning of an organization. Understanding how trust works in organizations is an essential challenge in the contemporary economy.

The acknowledged trust model that illustrates the factors affecting trust consists of three basic elements: ability, benevolence, and integrity [17]. It has been empirically confirmed that these factors have an impact on trust development [18]. Most studies have focused mainly on analyzing trust between subordinates and managers [19-22], but there are not enough studies that assess trust between co-workers [23]. Therefore, in this study we want to verify the conditions for trust both among employees and between employees and leaders. We want to establish what factors affect trust using the following independent variables: competences, relations, and cooperation. The primary goal of this study is to understand which of these factors are related to trust. The research described in this paper aims to determine whether there are links between trust and competences, relations, and cooperation. More specifically, we decided to examine whether better competences, relations, or cooperation are associated with higher levels of trust. Thus, we want to provide guidance on how to improve factors that are related to a high level of trust. Additionally, we want to encourage the development of specific business practices that help to maintain a sustainable organization.

This paper is organized as follows. First, we analyze the theoretical background and present the literature on sustainability, trust, and the relation between trust and competences, relations, and cooperation. Secondly, we outline the methodology used in this study to verify the research problems. We then present the results, and finally we discuss the conclusions and practical implications of this research.

\section{Conceptual Framework}

Sustainability in an enterprise is defined by Grudzewski and Hejduk as "an ability to constantly (1) learn, (2) adapt and develop, (3) revitalize, (4) reconstruct, (5) reorient, in order to maintain a stable and distinctive position on the market by offering outstanding value for customers both at the current time and in the future (in compliance with the paradigm of innovative growth) due to the organic variability that is characteristic of sustainable business models and the new possibilities and targets and ensuing responses to them, while balancing the interests of various groups" [24].

The concept of sustainability consists in applying the rules of sustainable development and a constructive combining of resources, aims, and strategic factors which are indispensable for the existence and development of organizations $[25,26]$. It should be emphasized that it is the organization itself which determines and identifies the common areas (denominators) in its economic, social, and environmental aims [27]. However, it may seem that effective management of the social responsibility of a company is impossible because of the difficulty in combining the varied and sometimes discrepant aims of effectively functioning in a competitive environment [28].

Organizational sustainability is encompasses the economic, societal, and environmental goals of an organization [29]. Sustainable organizations are capable of surviving whilst satisfying a triple bottom line of economic, environmental, and human performance [30] because sustainable development ensures simultaneous benefits in these three fields. Much research demonstrates that sustainable enterprises achieve better results in the long term than other companies [1,2,31]. This is made possible by the construction of a so-called sustainable business model which maintains an equilibrium between stakeholders' and shareholders' interests. At the same time, these enterprises implement management rules based on value and societal responsibility [32].

Organizations which operate in accordance with the sustainability model may be characterized by the following distinctive features:

- knowledge and trust are considered as dominating forms of capital [33],

- focus on teamwork and constant learning [33], 
- promotion of a proactive role in controlling the impact of the business on the natural environment, social environment, and human resources [34],

- taking into account social relationships (external and internal) in activities that aim to ensure long-term organizational effectiveness.

As can be seen from the above, what is emphasized is the significance of human capital as a factor that is essential in meeting the sustainable targets of an organization [3]. Human development is highlighted as the basis for the sustainable development of companies [35]. Building sustainable organizations is based on focusing on employees' skills, competences, motivations, and behavior [36]. Such a managerial attitude is a fundamental condition for sustainable development. It leads to mutual gain: employees fulfil their individual potential and improve the organization's intangible assets. Thus, both individuals and the organization gain a competitive advantage [37]. The practices of human resources management help to build sustainable organizations as a community of people which with time develop structures and behaviors and discover ways in which an entrepreneur becomes a sustainable employer [38].

Viewing a person in the light of the sustainability concept seems to combine contemporary approaches that are based on patterns of human behavior. Namely, it is a combination of knowledge, particular skills, particular talents, and attitudes adopted in the workplace and in the process of work [33]. It has been noted that behavioral sustainability in an organization requires particular conditions for its development; these include trust and cooperation with others, both of which are responsible for strengthening employees' inclination towards sustainable behaviors [39]. Furthermore, trust enables collaboration and collective transactions [40]. Additionally, trust in co-workers is associated with greater satisfaction with career advancement [41], and nurturing trust among employees and managers leads to increased productivity [16]. The importance of trust has been recognized as a driving force for innovative behaviors in sustainable organizations [12]. Furthermore, employees' willingness to maintain their work engagement is associated with trust, which can be improved by managerial practices that nurture and boost a supportive work environment [12].

The concept of sustainability is associated with corporate social responsibility (CSR), which is defined as voluntary actions and commitment aimed at achieving positive social and environmental changes [42]. CSR, whose concept is strongly focused on dialog and cooperation between an enterprise and its stakeholders [43], attempts to meet the needs of various groups of stakeholders. A sustainable organization should thoughtfully shape its relationships with all stakeholders in order to achieve long-lasting results, conduct business in compliance with their expectations, dutifully meet commitments, and use transparent business practices [44]. CSR projects result from strategic thinking through which companies endeavour to transform threats into opportunities [45]. An example of such threats is the turnover of key employees who have knowledge and skills that are essential for the enterprise to operate.

For this reason, high sustainability organizations focus on non-financial tools to build employees' commitment and motivation [46] (p. 23), while trust and cooperation are crucial for building social capital in these organizations [47].

\subsection{Definition of Trust}

A sustainable organization is based on trust [48]. Moreover, trust is a significant element responsible for achieving a competitive advantage [49]. The general definition of trust refers to the reciprocal assumption made by an individual in regard to another party's actions and their consequences [50]. Trust can be understood as the way an individual's attitude is affected by the way he/she perceives a particular relationship. This refers to confidence in the positive consequences of the actions of other parties [51]. Organizational trust means having positive expectations about an organization [22].

There are various scientific approaches to categorizing trust. The classification of Shapiro, Sheppard, and Cheraskins [52] assigns business trust to three categories: deterrence-based trust, knowledge-based trust, and identification-based trust. The analysis conducted on this model argues that this is a hierarchical concept of developing trust: one level of trust can arise only when the previous 
one is in place [53]. Another approach was presented by McAllister [54], who introduced two kinds of trust: cognition-related and affect-based. This concept states that cognition-based trust depends on the competency and reliability of the other side. Affect-related trust is established on the basis of interpersonal relationships. Additionally, Stranes, Truhon, and McCarthy [55] list three forms of organizational trust:

- interorganizational trust-refers to trust between two organizations;

- intraorganizational trust-describes trust between subordinates and managers, and between employees and the organization;

- interpersonal trust-concerns trust within relations and interconnections in teams.

Furthermore, Ting [56] distinguishes two types of interpersonal trust within organizations: towards managers and towards fellow employees. This can lead to the conclusion that there are two different aspects of interpersonal organizational trust. The first refers to whether a subordinate trusts their supervisor; the second focuses on trust relations between co-workers [57]. In summary, interpersonal trust consists of two dimensions: trust towards managers and trust towards fellow employees. This paper aims to explore both types of interpersonal trust in the business environment.

Additionally, Mayer, Davis, and Schoorman [17] focused on behavioral aspects of trust. In their research they emphasized the factors that determine the development of trust: competences, benevolence, and integrity. According to this model, trustworthiness depends on three factors: competence, which concerns the skills and abilities of the other person; benevolence, which reflects the relations and attachment between the two sides of the trust process [17] (p. 718); integrity, which is related to behavioral consistency [17] (p. 719). Understanding the conditions that can impact organizational trust provides information on how to improve organizational effectiveness.

The research framework in this study is based on the previous findings in the literature and emphasizes two aspects of interpersonal trust in organizations: rational trust based on the competences of other parties, and relation-oriented trust, which focuses on the bonds between involved persons. Rational aspects of trust will be analyzed through competences and self-efficacy; the relation elements of trust will be examined through relations and cooperation. We will study both horizontal (between co-workers) and vertical (between supervisors and subordinates) trust relations. The research problem focuses on the links between interpersonal trust and competences, relations, and cooperation. It is shown in Figure 1.

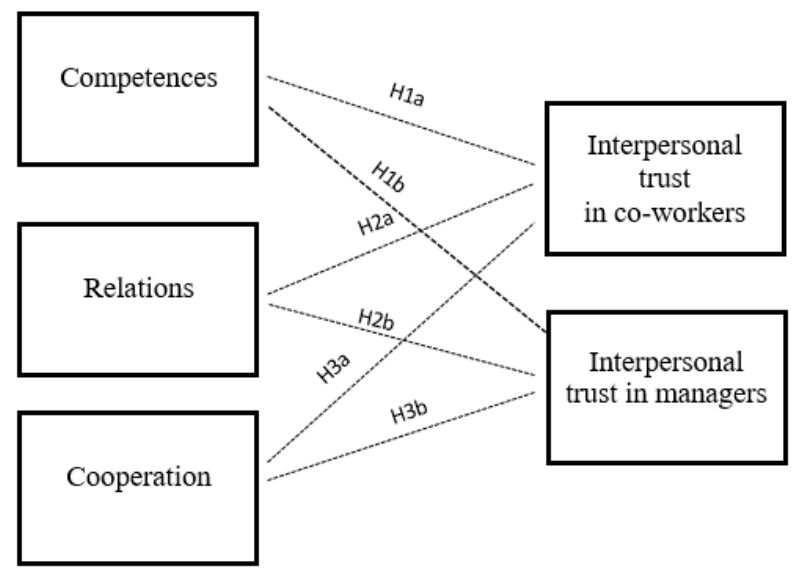

Figure 1. Conceptual model.

For the purpose of this research, trust is defined as positive expectations regarding another party's actions and behaviors towards an individual. We will examine trust as a phenomenon that affects organizational processes. The study will focus on interpersonal aspects of trust in organizations in the hope of providing suggestions for facilitating trust in sustainable organizations. 


\subsection{Competences}

Generally, competency is understood as capabilities that are based on one's knowledge, abilities, and attitudes [58]. A number of definitions of competence exist in the literature. The first group refers to employee's visible performance or behavior [59-62]. The second group describes competency as a standard or quality indicator [63]. The third group understands this term as an individual's characteristics [64]. All in all, the meaning of competency depends on the research approach.

For the purpose of this study, competency is used as an indicator of reliability in trust-building relations. We adopt the view that competency is understood as an ability or knowledge that helps in dealing with work-related tasks.

There are numerous ways of assessing competences, depending on their application [65]. Since competences understood as work-related ability can be successfully measured using quantitative methods [66], we adapt this approach in our study.

The rational perception of others and its relationship to trust in co-workers have been analyzed in previous research [67] but with conflicting results. In general, confidence based on another person's skills has been suggested to be an important element in trust development [68]. According to some research, ability was recognized as an important factor that affected trust in a Chinese sample, but not in a Turkish one [69]. Gill, Boies, Finegan, and McNally [70] established that situational context impacts the propensity to trust. This was in alignment with the results of Snijders and Keren [71]; it implies the importance for trust of situational factors. Similarly, trust is considered to be a result of cognitive factors such as reputation or credibility [72]. Ability and competences are also treated as a basis for trustworthiness by numerous scholars [73-75].

Furthermore, many scholars have identified ability or competency as a significant factor that influences organizational trust $[17,20,51,67,76]$. Consequently, rationale-based trust is established on the reasoning that one party will be able to fulfil the other's obligations. Subsequently, competency provides information that guides trust-related behaviors. Competency serves as a cognitive display of another person's trustworthiness [20]. Hence, the hypothesis states:

Hypothesis 1 (H1). Competency perception is positively related to interpersonal trust.

\subsection{Relation and Trust}

Focusing on the relationship aspect of trust, Colquitt, and Rodell state [77] that relationships among employees are an important trust-enhancing element. Furthermore, Tan and Lim [78] implied that benevolence is related to trust rather than ability. The emotional bonds among employees create a platform for trust development [67]. It has been confirmed that emotional aspects of trust are associated with emotions [79].

The importance of positive relations as a crucial element of building trust in organizations has increasingly been recognized $[5,80]$. Likewise, employee-oriented practices enhance trustworthiness in a given organization [81]. Similarly, a recent study shows that relationships and benevolence are vital in establishing trust in organizations [82]. Therefore, to examine this assumption the second hypothesis was formulated:

Hypothesis 2 (H2). The strength of a relationship is positively related to interpersonal trust.

\subsection{Cooperation and Trust}

It has been acknowledged that cooperation is associated with trust [83-85]. Cooperative conditions of trust lead to an increase in team confidence [86]. The two-way relation between trust and cooperation has been confirmed [87]. In the context of interpersonal trust, cooperation is perceived as a condition that determines trustworthiness. Kanter [88] acknowledged that cooperation is the cornerstone of 
building team confidence. Moreover, she recognized that cooperation creates a network of connections which helps in establishing trust-relations, hence the importance of cooperation in the model that represents how to nurture trust. We assume that a high level of cooperation is associated with a high level of organizational trust. Thus, the third hypothesis reflects this aspect of the conditions of trust:

Hypothesis $3 \mathbf{~ ( H 3 ) . ~ T h e ~ d e g r e e ~ o f ~ s u c c e s s f u l ~ c o o p e r a t i o n ~ i s ~ p o s i t i v e l y ~ r e l a t e d ~ t o ~ i n t e r p e r s o n a l ~ t r u s t . ~}$

Additionally, the formulated hypothesis will be verified in both the vertical and horizontal relations in an organization. Usually those are independent patterns of connections and interactions. Therefore, this study examines the links between trust in co-workers and trust in managers. Consequently, we hypothesized the following:

Hypothesis 1a (H1a). Competency perception is positively related to interpersonal trust between co-workers.

Hypothesis $\mathbf{1 b} \mathbf{( H 1 b ) . ~ C o m p e t e n c y ~ p e r c e p t i o n ~ i s ~ p o s i t i v e l y ~ r e l a t e d ~ t o ~ i n t e r p e r s o n a l ~ t r u s t ~ i n ~ m a n a g e r s . ~}$

Hypothesis 2a (H2a). The strength of relationships is positively related to interpersonal trust between co-workers.

Hypothesis $\mathbf{2 b} \mathbf{b} \mathbf{H} \mathbf{2} \mathbf{b})$. The strength of relationships is positively related to interpersonal trust in managers.

Hypothesis 3a (H3a). The degree of successful cooperation is positively related to interpersonal trust between co-workers.

Hypothesis $\mathbf{3 b} \mathbf{b} \mathbf{H} \mathbf{b} \mathbf{b})$. The degree of successful cooperation is positively related to interpersonal trust in managers.

\section{Method}

\subsection{Sampling}

The empirical research applied in this study was used to analyse the relation between trust (dependent variable) and competences, relations, and cooperation (independent variables). Data were collected via questionnaires among employees of telecommunications companies $(n=175)$. The telecommunications services sector is among the fastest developing sectors in the modern economy. It is a sector that combines advanced technologies with a high level of innovation and considerable investment. Productivity and profitability in telecommunications companies are often significantly above average in the non-financial business economy. Turnover and added value in telecommunications services are steadily increasing in spite of falling tariffs and pricing [89]. The telecommunications services market encompasses both wireless and wireline services, which are some of the most profitable segments in the IT industry. In 2015, global telecommunications services generated approximately 1.1 trillion euros in revenues. The great significance and potential in this industry was recorded in Europe, where in 2015 it produced around one-quarter of total revenue [90]. The research was conducted in a group of telecommunications companies in Poland, in which the turnover of the telecommunications sector amounted to approximately 10 billion euros in 2014 [89]. Statistics show that on average in OECD countries in 2011, jobs in the information and communication technology (ICT) sector represented 3.7\% of business sector employment [91]. In Poland in 2014 the telecommunications sector employed 48,794 people [89].

The Office of Electronic Communications' register of telecommunications companies operating in Poland was used as a framing sample (it includes all organizations that provide telecommunications services in Poland that are obliged to register under the Telecommunications Act, 2004) [92]. When choosing the types of business enterprises (LLC, stock-offering companies) we established the research 
population and consequently obtained the research sample, $n=175$. The questionnaire was distributed via e-mails (108 questionnaires) and in person by the author (67 questioners). The respondents' confidentiality was assured. The basic introduction to the research topic was described in the headline of the survey. Data were entered and coded using Excel.

The sample contained $34.86 \%$ (61) women and $65.14 \%$ (114) men; $84 \%$ (147) declared that they were employees of telecommunications organizations; $13.14 \%$ (23) were IT sector employees; $2.86 \%$ (5) were employees in other sectors. The number of respondents in the companies varied: enterprises with 251 and more employees-77.14\% (135); organizations with 51-250 employees-13.14\% (23); organizations with $11-50$ employees- $7.43 \%$ (13). More than half the respondents had over 10 years' professional experience $60 \%$ (105); $22.86 \%$ (40) had 1-5 years' experience; $13.71 \%$ (24) had 6-10 years' experience; $3.43 \%$ (6) had less than a year of professional experience. The following positions were represented: directors $5.14 \%$ (9); managers $18.29 \%$ (32); specialists $67.43 \%$ (118); experts $3.43 \%$ (6); analysts $1.71 \%$ (3); assistants $0.57 \%$ (1); others $3.43 \%$ (6). Among respondents, $67.43 \%$ (118) had a master's degree; $17.71 \%$ (31) had a bachelor's degree; $11.43 \%$ (20) had an engineer's degree; $1.14 \%$ (2) had a high-school diploma; $2.29 \%$ (4) of questionnaires were left blank.

\subsection{Measures}

There were four items in this questionnaire: trust, competences, relations, and cooperation. Each item consists of statements that were based on indicators. All items in the questionnaire were rated on a five-point Likert-type scale ( 1 "strongly disagree", 5 "strongly agree"). The Likert scale is an appropriate tool to measure trust within an organization [80,93-95]. The respondents were asked to refer to the team they currently work in when answering questions.

The indicators were operationalized according to the conceptualization presented in Table 1.

Table 1. The conceptual framework.

\begin{tabular}{|c|c|c|c|}
\hline \multicolumn{2}{|c|}{ Variable } & Dimension & Theoretical Background \\
\hline \multirow{2}{*}{$\begin{array}{l}\text { Dependent } \\
\text { variable }\end{array}$} & \multirow{2}{*}{$\begin{array}{l}\text { Interpersonal } \\
\text { trust }\end{array}$} & Trust in supervisor & $\begin{array}{l}\text { Ermisch, Gambetta, Laurie, Siedler, Uhrig, 2009; [96] } \\
\text { Oh, Park, } 2011 \text { [97]; Wu, Lin, Hsu, Yeh, } 2009 \text { [98] }\end{array}$ \\
\hline & & Trust in co-workers & Moye, Henkin, 2006 [99]; Rotter, 1967 [100] \\
\hline \multirow{5}{*}{$\begin{array}{l}\text { Independent } \\
\text { variables }\end{array}$} & Competences & Team competences & $\begin{array}{l}\text { Margerison, } 2001 \text { [101]; Meyer, Brünig, Nyhuis, } 2015 \text { [102]; } \\
\text { Waters, Sroufe, } 1983 \text { [103]; Knoll, Gill, } 2010 \text { [23]; } \\
\text { Robotham, Jubb, } 1996 \text { [104] }\end{array}$ \\
\hline & \multirow{2}{*}{ Relations } & Team relations & $\begin{array}{l}\text { Wiese, Botha, van Heerden, } 2015 \text { [105]; Tierney, } 1999 \text { [106]; } \\
\text { Forret, Love, } 2008 \text { [107]; Hornsey, Hogg, } 2000 \text { [108] }\end{array}$ \\
\hline & & Emotional bonds & $\begin{array}{l}\text { Price, } 2013 \text { [109]; Shih-Tse Wang, } 2014 \text { [110]; } \\
\text { Graf, Ausserhofer, Schwendimann, Zúñiga, } 2015 \text { [111] }\end{array}$ \\
\hline & \multirow[b]{2}{*}{ Cooperation } & Team cooperation & Nonose, Kanno, Furuta, 2014 [112]; Sun, Qi, 2004 [113] \\
\hline & & Team cohesion & $\begin{array}{l}\text { Grossman, Rosch, Mazer, Salas, } 2015 \text { [114]; } \\
\text { Knott, Geyer, Sidman, Wiese, } 2011 \text { [115]; } \\
\text { "Team Cohesion" } 2007 \text { [116] }\end{array}$ \\
\hline
\end{tabular}

Source: own elaborations.

\subsubsection{Dependent Variable}

The measures for trust were developed based on the literature. The first variable, "trust in supervisor", is based on Mayer and Gavin's [117] and Mayer and Davies' [118] instrument. It consists of three items: "I would be willing to let my supervisor have substantial control over my future in the company", "I can talk freely with my supervisor", "I have confidence in my supervisor". A three-item measure was developed to evaluate trust in co-workers. It was based on an instrument used by Forret and Love [107] and Poon [119]. Trust in co-workers was assessed by having participants indicate their level of agreement with the following statements: "Most of my co-workers can be relied upon 
to do their work", "Most of my co-workers are trustworthy", "I have confidence in my co-workers". The Cronbach's alpha of Trust was 0.76 .

\subsubsection{Independent Variables}

Competences were assessed by a two-item scale based on Naim and Lenka [120]. The respondents were asked to indicate their opinion on the following statements: "My team has the ability to complete a task", "My team is very competent". The relations measure was developed as: "My team is like a community", "I feel part of a team", "There are strong emotional relations between the members of my team". In order to assess cooperation, the participants were asked to express their opinion about the following statements: "Cooperation in my team is good", "My team pursues its goals collaboratively" $[115,121]$. The Cronbach's alpha for items in this measure was: competences 0.87 , relations 0.84 , cooperation 0.94 .

\subsubsection{Control Variable}

Since the relation between generalized trust and trust in business organizations has been recognized [122], we decided to include this variable in our analyses. Assuming that trusting people are more likely to display higher levels of trust in co-workers and managers, it might bias the results of our research. Therefore, generalized trust was controlled in this study.

\section{Results}

Trust among respondents was generally high. However, the average trust in co-workers $(\mathrm{M}=0.4)$ was higher than the average trust in managers $(M=3.69)$. The average generalized trust $(M=3.96)$ was lower than the average trust declared by fellow employees, but higher than the average trust in managers. Table 2 provides the percentage of responses to questions relating to interpersonal trust. Generalized trust was used as an indicator of a person's individual attitude towards others and helps in estimating the results; $65 \%$ of respondents trust co-workers ( $24 \%$ "strongly agree" and $40 \%$ "rather agree"); only $3.43 \%$ (disagree $2.86 \%$ and strongly disagree $0.57 \%$ ) disagree with the statements relating to trust in co-workers. This indicates that trust in fellow employees is very high (higher than generalized trust). In comparison, $12 \%$ declared that they do not trust their leader (3.43\% rather disagree and $8.57 \%$ strongly disagree with the statement referring to trust in the leader).

Table 2. Interpersonal trust.

\begin{tabular}{cccccccc}
\hline & \multicolumn{7}{c}{ Profile of Responses } \\
\cline { 2 - 8 } & $\mathbf{M}$ & $\mathbf{N}$ & $\mathbf{1}$ & $\mathbf{2}$ & $\mathbf{3}$ & $\mathbf{4}$ & $\mathbf{5}$ \\
\hline Trust co-workers & 4.4 & 175 & 1 & 5 & 22 & 105 & 42 \\
Trust leader & 3.70 & 175 & 6 & 15 & 38 & 83 & 33 \\
Generalized trust & 3.96 & 175 & 1 & 8 & 27 & 100 & 39
\end{tabular}

Notes: 5-Strongly agree, 4-Rather agree, 3-Neither agree nor disagree, 2—Rather disagree, 1—Strongly disagree. Source: own elaboration.

In conclusion, this illustrates that in the research sample there is a high level of trust among employees. It also implies greater distrust (four times more) in managers than between peer employees.

\section{Verification of Hypotheses}

Both H1a and H1b were strongly supported. Moderate positive correlations were found between trust in co-workers and evaluation of the team's competence $(r=0.438, p=0.000)$ and between trust in the manager and competences $(r=0.298, p=0.000)$. The result of correlation analysis is presented in Table 3. It implies that competences are related positively to interpersonal organizational trust. 
Table 3. Intercorrelation matrix.

\begin{tabular}{lcccccc}
\hline & $\mathbf{1}$ & $\mathbf{2}$ & $\mathbf{3}$ & $\mathbf{4}$ & $\mathbf{5}$ & $\mathbf{6}$ \\
\hline 1. Competences & 1 & & & & & \\
2. Cooperation & $0.800^{* *}$ & 1 & & & & \\
3. Relations & $0.720^{* *}$ & $0.730^{* *}$ & 1 & & & \\
4. Generalized trust & 0.107 & 0.084 & 0.094 & 1 & & \\
5. Trust to co-workers & $0.468^{* *}$ & $0.535^{* *}$ & $0.499^{* *}$ & $0.425^{* *}$ & 1 & \\
6. Trust to manager & $0.431^{* *}$ & $0.480^{* *}$ & $0.389^{* *}$ & $0.185^{*}$ & $0.624^{* *}$ & 1 \\
\hline
\end{tabular}

Notes: ${ }^{*} p<0.05 ;{ }^{* *} p<0.01$. Source: own elaboration.

To further explore these relations, a one-way ANOVA analysis was conducted. To examine the links between trust in co-workers and competence level, three groups of trust in co-workers were distinguished: low trust level $(\mathrm{M}=3.21$, $\mathrm{SD}=1.07)$, medium trust level $(\mathrm{M}=4.12, \mathrm{SD}=0.73)$, and high trust level $(\mathrm{M}=4.5, \mathrm{SD}=0.55)$. There was a significant difference in evaluation of mean competences $(\mathrm{F}(2,172)=24.91, p<0.001)$ between the different levels of trust. Those with a low level of trust in their peers have the lowest average level of trust. Those with the highest level of trust were characterized by the highest assessment level of competences. Post hoc $t$-test comparisons using Bonferroni correction, with adjusted alpha $\left(\left(\alpha_{\text {altered }}=0.05 / 3\right), 0.016\right.$ per test $)$ confirmed that there were statistically significant differences in competences between the low trust group $(\mathrm{M}=3.21, \mathrm{SD}=1.07)$ and the high trust group $(\mathrm{M}=4.5$. $\mathrm{SD}=0.55), t(37)=-5.88, p=0.000$. The verification describes statistically significant differences between competences in medium and high trust level groups $(t(99)=3.38, p=0.000)$, as well as low and medium trust groups $(t(34)=-4.25, p=0.000)$. Hence, this supports Hypothesis H1a.

To analyze whether there were statistically important differences in relations between competences and trust in managers, a one-way ANOVA analysis was conducted on three groups: low trust $(\mathrm{M}=3.78, \mathrm{SD}=0.98)$, medium trust $(\mathrm{M}=4.11, \mathrm{SD}=0.78)$, and high trust $(\mathrm{M}=4.48, \mathrm{SD}=0.57)$. There was a significant effect of competences on trust in managers $(\mathrm{F}(2,172)=7.96, p<0.001)$. A further post hoc test using an altered alpha value (0.016) confirmed the significant differences between the low trust group $(\mathrm{M}=3.78, \mathrm{SD}=0.98)$ and the high trust group $(\mathrm{M}=4.48, \mathrm{SD}=0.57)$ in mean competences $(t(90)=-4.36$, $p<0.001)$. These results indicate that competences level affects trust in managers in an organization. In consequence, it supports Hypothesis H1b.

There was a positive correlation between trust in co-workers and relationships $(r=0.499, p<0.000)$. Additionally, emotional bonds were positively correlated to trust in fellow employees $(r=0.419, p<0.000)$. These results demonstrate the links between relations and interpersonal trust in co-workers. The one-way ANOVA analysis indicates that there is a significant difference between trust in co-workers depending on relations $(\mathrm{F}(2,172)=23.174, p<0.001)$. A post hoc $t$-test with Bonferroni correction $\left(\alpha_{\text {altered }}=0.05 / 3\right)$ 0.016 supported this result $(t(41)=-6.15, p<0.000)$. The high trust group $(\mathrm{M}=4.35, \mathrm{SD}=0.65)$ was characterized by a higher average level of relations in comparison to the low trust group $(M=2.96$, $\mathrm{SD}=0.2)$. The relationship also varied among low and medium trust $(t(37)=-4.59, p=0.000)$ and medium and high trust $(t(98)=2.93, p=0.002)$. This provides further support for Hypothesis H2a.

The correlation between trust in managers and relationships $(r=0.389, p=0.000)$ shows that confidence in managers is related to relationships in an organization. An additional one-way ANOVA analysis suggested a significant difference between trust in managers and average relations $(\mathrm{F}(2,172)=8.11, p<0.001)$. This was confirmed by a series of post hoc $t$-tests $\left(\left(\alpha_{\text {altered }}=0.05 / 3\right) 0.016\right)$, $\mathrm{t}(89)=-3.87, p=0.001$, since relations were significantly different in the low trust $(\mathrm{M}=3.54, \mathrm{SD}=1.14)$ and high trust $(\mathrm{M}=4.30, \mathrm{SD}=0.72)$ groups. Moreover, relations were different for the low and medium trust $(\mathrm{M}=4, \mathrm{SD}=0.79)$ groups. This supports Hypothesis $\mathrm{H} 2 \mathrm{~b}$.

There was a moderate significant correlation between cooperation and trust in co-workers $(r=0.486, p=0.000)$ and group cohesion $(r=0.535, p=0.000)$. The one-way ANOVA variance analysis indicated that cooperation is significantly different for low, medium, and high trust groups $(\mathrm{F}(2,172)=21.398, p<0.001)$. The series of post hoc $\mathrm{t}$-tests with Bonferroni correction and adjusted alpha 
emphasizes that cooperation was much more positively evaluated in groups characterized by high trust between co-workers $(\mathrm{M}=4.26, \mathrm{SD}=0.79)$ than in low trust groups $(\mathrm{M}=2.82, \mathrm{SD}=1.21), t(42)=-5.51$, $p<0.001$. Cooperation was a significant factor that distinguishes trust in fellow employees between low and medium trust $(\mathrm{M}=3.88, \mathrm{SD}=0.88)$ groups $(t(37)=-3.61, p<0.001)$, as well as medium and high trust groups $(t(89)=3.45, p<0.001)$. The difference between average cooperation and low and medium trust $(t(37)=3.61, p=0.000)$ was statistically important. By illustrating the positive links between cooperation and trust in peers, this calculation supports Hypothesis $\mathrm{H} 3 \mathrm{a}$, and Hypothesis $\mathrm{H} 3 \mathrm{~b}$ was also confirmed. A moderate significant correlation was discovered between trust in managers and cooperation $(r=0.431, p=0.000)$. Moreover, the cohesion was also correlated to trust in supervisors $(r=0.480, p=0.000)$. Further examination of this relation was conducted using one-way ANOVA analysis. The test $(\mathrm{F}(2,172)=10.65, p<0.001)$ established that average cooperation is different in low, medium, and high trust groups. Those who trust managers the least $(\mathrm{M}=3.37, \mathrm{SD}=1.15)$ were characterized by the lowest level of cooperation. In contrast, those who trust their supervisor the most $(\mathrm{M}=4.30, \mathrm{SD}=0.76)$ have the highest cooperation scores. A further series of post hoc t-tests with adjusted alpha value (0.0167) revealed that high and low level of trust in managers was statistically related to cooperation $(t(87)=-4.61, p<0.001)$. Similarly, cooperation levels significantly differ in medium and low trust groups $(t(68)=-2.32, p=0.011)$. Average cooperation varies in low and medium trust groups $(t(105)=3.01, p=0.001)$. This provided further support for Hypothesis H3b.

Generalized trust, which was used as an indicator of average individual trust level, was not significantly correlated to any variable.

In pursuance of establishing the determinants of interpersonal trust, a linear multiplied regression analysis was conducted. In H1a, H2a, and H3a we proposed that trust in co-workers is predicted by competences, relations, and cooperation. The findings of statistical analysis suggest that combined competences, relations, and cooperation account for a statistically significant proportion of variance in trust in co-workers $\mathrm{F}(3,171)=25.62851, p<0.001$ and accounted for $31 \%$ of the variance in trust in co-workers with adj. $R^{2}$ of 0.31 . The Beta weight for cooperation was not statistically significant ( $\beta=0.151, t=1.558159, p=0.12)$. This indicates that only competences $(\beta=0.215, t=2.785, p=0.002)$ and relations $(\beta=0.287, t=3.119, p=0.005)$ contributed to the variance in trust in co-workers.

A multiple linear regression was calculated to examine the relations between competences, relations, cooperation, and trust in managers. The analysis results indicate that together these factors explain $20 \%$ of the variance in trust in managers $(F(3,171)=14.655, p<0.001)$ with adj. $R^{2}=0.204$. Cooperation was the only component that predicted trust in managers $(\beta=0.295, t=2.820, p=0.005)$.

\section{Discussion}

The research hypotheses were formulated to show that interpersonal trust is partly connected by two main factors. The first condition involves the cognitive process of rationally analysing the trustworthiness of a second agent based on his/her abilities. The second factor refers to the emotional perception of the state of the relationship between co-workers based on relations and cooperation in teams. In our research, both cognitive and emotional aspects of interpersonal trust were examined to provide an understanding of the specific patterns that are associated with an increased level of organization.

The verification of Hypothesis H1a has implications for the importance of strengthening the cognitive aspect of interpersonal trust. Competences are correlated with trust in fellow employees. These findings align with $[20,67]$. However, our results are focused on a specific sector. The presented study analyses the telecommunications sector and helps to examine its unique characteristics. The studied telecommunications employees' trust in their co-workers is associated with the team's competences. Similarly, the examination of Hypothesis H1b points to the fact that recognition of competences affects trust in managers. This corresponds with the literature on trust antecedents [21]. Further analysis indicates that perception of abilities is an important factor that is related to trust. This is a significant finding which emphasizes the role of competences in organizational confidence. 
Hypothesis H2a suggests that emotional conditions related to trust play an important role in building trust. The analyses provide an insight which illustrates that employees who have good interpersonal relations and emotional bonds have a higher level of trust. Furthermore, our research supports previous studies which indicate a connection between trust and interpersonal relations [67].

Additionally, the emotional aspect of trust in supervisors is also confirmed (H2b). This is in alignment with earlier findings [19]. The main contribution of this study indicates that interpersonal relationships are strongly related to organizational trust. Furthermore, increased positive interactions facilitate interpersonal trust.

The examination of Hypothesis $\mathrm{H} 3$ provides support for links between cooperation and trust. Cooperation is correlated with organizational confidence. This corresponds with both theoretical assumptions [123] and practical studies [112,124] and demonstrates the importance of good cooperative patterns that enhance organizational trust. The interpersonal trust relationship model is illustrated in Figure 2.

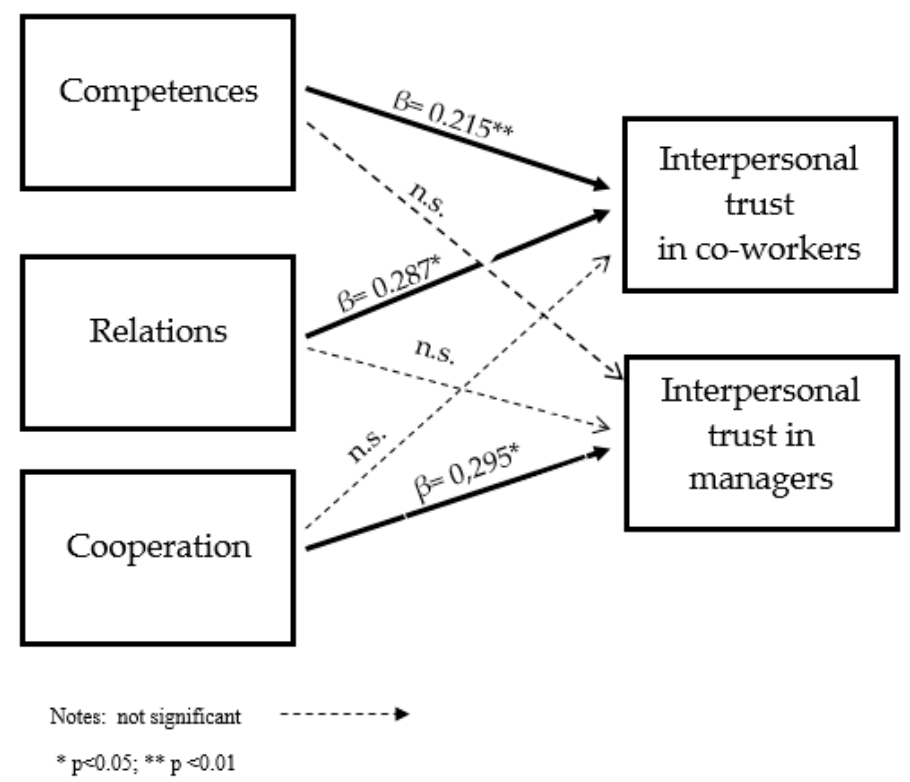

Figure 2. Relationship model.

Overall, the study confirmed the results of McAllister [54], who recognized the cognitive and affective foundations of trust. Our findings show that in order to strengthen organizational confidence, both ability and competences as well as relations and cooperation should be improved. According to these results, organizational practices that facilitate trust should emphasize both the cognitive and emotional aspects of trust. Developing competences, creating opportunities for interaction, and improving cooperation are core elements of organizational interpersonal trust.

More precisely, our study assessed the factors that determine interpersonal trust in organizations. Consistent with our hypotheses, we found that trust in co-workers is related to competences and relations. However, cooperation was not a significant predictor of trust in fellow employees. This implies that creating opportunities to bond and maintain good relationships among peers in organizations and building work-related ability and skills help to improve interpersonal trust between co-workers. On the contrary, in order to build trust in managers, one should stress the need for successful cooperation as this determines trust in supervisors. Thus, it seems that it is important for employees to demonstrate proficiency to be considered trustworthy. Furthermore, positive group interaction leads to improved group trust. Managers should focus on maintaining successful cooperation to build their own credibility. The core components for building organizational confidence are competence, relations (for co-workers), and cooperation (for managers). 
The practical implications of our study indicate the significance of cognitive and affective factors in building trust. One of the most important conclusions of this study is that it provides evidence of the importance of creating trust-enhancing organizations by improving employees' competences and providing space for bonding activities that nurture interpersonal relations. Employees' trust is associated with abilities and relationships. Hence, by providing adequate support (such as training and integration opportunities), one is able to improve interpersonal trust in organizations.

In conclusion, our findings suggest that interpersonal trust in sustainable organizations is associated with cognitive and affective factors. Since trust is a core element of sustainable development [125], implementation of practices that enhance team confidence improves the way these organizations function. Additionally, understanding various aspects that influence interpersonal trust in sustainable organizations helps to reinforce the development of organizational trust. There are two basic strategies that can help to improve trust: firstly, strengthening competences and abilities; secondly, building mutual relationships and improving cooperation. According to our results, it is especially important to develop and subsequently maintain positive trust-oriented bonds between employees and managers. Sustainable management involves encouraging confidence and improving the quality of social aspects of work by strengthening trust. Our study provides guidance which specifies the core aspects of establishing interpersonal trust in sustainable organizations.

Further research could be conducted in different countries to provide cross-cultural comparisons. Moreover, future analysis could explore more aspects of interpersonal trust. Furthermore, the analysis only considers three conditions related to trust. Further exploration of additional elements that affect interpersonal trust is required. Even though we acknowledge some limitations of this research, we support our claim that competences, relations, and cooperation affect interpersonal trust.

Author Contributions: These authors contributed equally to this work. All authors read and approved the final manuscript.

Funding: The research for this paper has been conducted in the framework of projects no. S/WZ/2/2015 and 203689/E-365/S/2018 financed from the funds of the Ministry of Science and Higher Education of Poland.

Conflicts of Interest: The authors declare no conflict of interest.

\section{References}

1. Wales, T. Organizational Sustainability: What Is It, and Why Does It Matter? REAMS 2013, 1, 38-49.

2. Alshehhi, A.; Nobanee, H.; Khare, N. The Impact of Sustainability Practices on Corporate Financial Performance: Literature Trends and Future Research Potential. Sustainability 2018, 10, 494. [CrossRef]

3. Kim, W.; Khan, G.F.; Wood, J.; Mahmood, M.T. Employee Engagement for Sustainable Organizations: Keyword Analysis Using Social Network Analysis and Burst Detection Approach. Sustainability 2016, 8, 631-642. [CrossRef]

4. Hejduk, I. Sustainable Enterprise as a Concept of Contemporary Management. Przeds. Zarz. 2016, 10, 9-20.

5. Hansen, S.D.; Dunford, B.B.; Boss, A.D.; Boss, R.W.; Angermeier, I. Corporate Social Responsibility and the Benefits of Employee Trust: A Cross-Disciplinary Perspective. J. Bus. Ethics 2011, 102, 29-45. [CrossRef]

6. Gharleghi, B.; Jahanshahi, A.A.; Nawaser, K. The Outcomes of Corporate Social Responsibility to Employees: Empirical Evidence from a Developing Country. Sustainability 2018, 10, 698. [CrossRef]

7. Edgeman, R.; Neely, A.; Eskildsen, J. Paths to sustainable enterprise excellence. J. Model. Manag. 2016, 11, 858-868. [CrossRef]

8. Day, C. Building and sustaining successful principalship in England: The importance of trust. J. Educ. Adm. 2009, 47, 719-730. [CrossRef]

9. Costa, A.C. Work team trust and effectiveness. Pers. Rev. 2003, 32, 605-622. [CrossRef]

10. Siebert, S.; Martin, G. People management rationales and organizational effectiveness: The case of organizational trust repair. J. Organ. Eff. People Perform. 2014, 1, 177-190. [CrossRef]

11. Muethel, M.; Siebdrat, F.; Hoegl, M. Interpersonal trust in globally dispersed NPD-teams. R D Manag. 2011, 42,31-46. [CrossRef] 
12. Yu, M.C.; Mai, Q.; Tsai, S.B.; Dai, Y. An Empirical Study on the Organizational Trust, Employee-Organization Relationship and Innovative Behavior from the Integrated Perspective of Social Exchange and Organizational Sustainability. Sustainability 2018, 10, 864. [CrossRef]

13. Ouedraogo, N.; Ouakouak, M.L. Impacts of personal trust, communication, and affective commitment on change success. J. Organ. Chang. Manag. 2018, 31, 676-696. [CrossRef]

14. Lopez-Fresno, P.; Savolainen, T.; Miranda, S. Role of Trust in Integrative Negotiations. Electron. J. Knowl. Manag. 2018, 16, 13-22.

15. Gordon, G. Applied Trust Leadership. In Leadership through Trust; Gordon, G., Ed.; Palgrave Macmillan: Basingstoke, UK, 2017; pp. 23-51.

16. Bendickson, J.; Muldoon, J.; Ligouri, E.; Midgett, C. High performance work systems: A necessity for startups. J. Small Bus. Strategy 2017, 27, 1-12.

17. Mayer, R.C.; Davis, J.H.; Schoorman, F.D. An Integrative Model of Organizational Trust. Acad. Manag. Rev. 1995, 20, 709-734. [CrossRef]

18. Colquitt, J.A.; Scott, B.A.; LePine, J.A. Trust, Trustworthiness, and Trust Propensity: A Meta-Analytic Test of Their Unique Relationships with Risk Taking and Job Performance. J. Appl. Psychol. 2007, 92, 909-927. [CrossRef] [PubMed]

19. Yagil, D. Trust in the supervisor and authenticity in service roles. J. Serv. Manag. 2014, 25, 411-426. [CrossRef]

20. Poon, J.M.L. Effects of benevolence, integrity, and ability on trust-in-supervisor. Empl. Relat. 2013, 35, 396-407. [CrossRef]

21. Nienaber, A.M.; Romeike, P.D.; Searle, R.; Schewe, G. A qualitative meta-analysis of trust in supervisorsubordinate relationships. J. Manag. Psychol. 2015, 30, 507-534. [CrossRef]

22. Tan, H.H.; Tan, C.S. Toward the differentiation of trust in supervisor and trust in organization. Genet. Soc. Gen. Psychol. Monogr. 2000, 126, 241-260. [PubMed]

23. Knoll, D.L.; Gill, H. Antecedents of trust in supervisors, subordinates, and peers. J. Manag. Psychol. 2011, 26, 313-330. [CrossRef]

24. Grudzewki, W.M.; Hejduk, I.K. Przedsiębiorstwo przyszłości. Zmiany paradygmatów Zarządzania. Master Bus. Adm. 2011, 1, 95-111. (In Polish)

25. Kożuch, B.; Sienkiewicz-Małyjurek, K. Inter-Organisational Coordination for Sustainable Local Governance: Public Safety Management in Poland. Sustainability 2016, 8, 123. [CrossRef]

26. Jabłoński, A. Wieloparadygmatyczność w zarządzaniu a trwałość modelu biznesu przedsiębiorstwa. Stud. Prace Kol. Zarz. Finans. Szkoty Głównej Hand. Warsz. 2014, 139, 51-72. (In Polish)

27. Truant, E.; Corazza, L.; Scagnelli, S.D. Sustainability and Risk Disclosure: An Exploratory Study on Sustainability Reports. Sustainability 2017, 9, 636. [CrossRef]

28. Michelson, G.; Waring, P.; Naude, P. International perspectives on corporate social responsibility Dilemmas and challenges in corporate social responsibility. J. Gen. Manag. 2016, 41, 1-11.

29. Nawaz, W.; Koç, M. Development of a systematic framework for sustainability management of organizations. J. Clean. Prod. 2018, 171, 1255-1274. [CrossRef]

30. Spreitzer, G.; Porath, C.L.; Gibson, C.B. Toward human sustainability: How to enable more thriving at work. Organ. Dyn. 2012, 41, 155-162. [CrossRef]

31. Hategan, C.D.; Sirghi, N.; Curea-Pitorac, R.I.; Hategan, V.P. Doing Well or Doing Good: The Relationship between Corporate Social Responsibility and Profit in Romanian Companies. Sustainability 2018, 10, 1041. [CrossRef]

32. Jabłoński, A. Scalability of Sustainable Business Models in Hybrid Organizations. Sustainability 2016, 8, 194. [CrossRef]

33. Hilarowicz, A. Rola i znaczenie kapitału ludzkiego w koncepcji. Zesz. Nauk. 2015, 85, 141-152. (In Polish)

34. Ehnert, I.; Harry, W.; Zink, K.J. Sustainability and HRM. An introduction to the field. In Sustainability and Human Resources Management. Developing Sustainable Business Organizations; Ehnert, I., Harry, W., Zink, K.J., Eds.; Springer: Berlin/Heidelberg, Germany, 2014; p. 5.

35. Jiang, W.; Zhao, X.; Ni, J. The Impact of Transformational Leadership on Employee Sustainable Performance: The Mediating Role of Organizational Citizenship Behavior. Sustainability 2017, 9, 1567. [CrossRef]

36. Pfeffer, J. Building sustainable organizations: The human factor. Acad. Manag. Perspect. 2010, $24,34-45$. [CrossRef] 
37. Iles, P. Sustainable high-potential career development: A resource-based view. Career Dev. Int. 1997, 2, 347-353. [CrossRef]

38. Romanelli, M. Organizations and People for Sustainability. Manag. Dyn. Knowl. Econ. 2018, 6, 117-128. [CrossRef]

39. Zabel, H.U. A model of human behaviour for sustainability. Int. J. Soc. Econ. 2005, 32, 717-734. [CrossRef]

40. Aras, G.; Crowther, D. What Level of Trust is Needed for Sustainability? Soc. Responsib. J. 2007, 3, 60-68. [CrossRef]

41. Han, G. Trust and career satisfaction: The role of LMX. Career Dev. Int. 2010, 15, 437-458. [CrossRef]

42. Aguilera, R.V.; Rupp, D.E.; Williams, C.A.; Ganapath, I.J. Putting The S Back In Corporate Social Responsibility: A Multilevel Theory Of Social Change In Organizations. Acad. Manag. Rev. 2007, 32, 836-863. [CrossRef]

43. Matuszak, Ł.; Różańska, E. CSR Disclosure in Polish-Listed Companies in the Light of Directive 2014/95/EU Requirements: Empirical Evidence. Sustainability 2017, 9, 2304. [CrossRef]

44. Lisiecka, K. Społeczna odpowiedzialność w relacjach z interesariuszami w systemie ochrony zdrowia. Res. Papers Wroc. Univ. Econ. 2015, 378, 296-308. (In Polish) [CrossRef]

45. Raufflet, E.; Cruz, L.B.; Bres, L. An assessment of corporate social responsibility practices in the mining and oil and gas industries. J. Clean. Prod. 2014, 84, 256-270. [CrossRef]

46. Eccles, R.G.; Ioannou, I.; Serafeim, G. The Impact of Corporate Sustainability on Organizational Processes and Performance. Available online: http:/ / ssrn.com/abstract=1964011 (accessed on 10 April 2018).

47. Grudzewki, W.M.; Hejduk, I.K. Sustainable enterprise (przedsiębiorstwo przyszłości)—Odpowiedzią na kryzys ekonomiczny. In Sustainability Odpowiedzia na Kryzys Ekonomiczny. Nowe Koncepcje Przedsiębiorstwa Przyszłości; Hejduk, I.K., Ed.; Orgmasz: Warszawa, Poland, 2011; pp. 20-22. ISBN 978-83-60561-07-2.

48. Beckett, R.C.; Jones, M. The Variable Nature of Trust in Sustainable Collaborative Ventures. In Collaborative Networks for a Sustainable World; Camarinha-Matos, L.M., Boucher, X., Afsarmanesh, H., Eds.; Springer: New York, NY, USA, 2010; Available online: https:/ /www.springer.com/la/book/9783642159602 (accessed on 4 April 2018).

49. Barney, J.B.; Hansen, M.H. Trustworthiness as a source of competitive advantage. Strateg. Manag. J. 1994, 175-190. [CrossRef]

50. Gambetta, D. Can We Trust? In Trust: Making and Breaking Cooperative Relations; Gambetta, D., Ed.; Department of Sociology, University of Oxford: Oxford, UK, 2000; Chapter 13; pp. 213-237.

51. Cook, J.; Wall, T. New work attitude measures of trust, organizational commitment and personal need non-fulfilment. J. Occup. Organ. Psychol. 1980, 53, 39-52. [CrossRef]

52. Shapiro, S.P.; Sheppard, B.H.; Cheraskin, L. Business on a handshake. Negot. J. 1992, 8, 365-377. [CrossRef]

53. Roy, J.; Lewicki, E.C.; Tomlinson, N.G. Models of Interpersonal Trust Development: Theoretical Approaches, Empirical Evidence, and Future Directions. J. Manag. 2006, 32, 991-1022. [CrossRef]

54. McAllister, D.J. Affect and cognition-based trust as foundations for interpersonal cooperation in organizations. Acad. Manag. J. 1995, 38, 24-59. [CrossRef]

55. Stranes, B.; Truhon, S.; McCarthy, V. Organizational Trust: Employee-Employer Relationships. A Primer on Organizational Trust. 2015. Available online: https://asq.org/hdl/2010/06/a-primer-on-organizational-trust.pdf (accessed on 10 September 2016).

56. Ting, Y. Determinants of job satisfaction of Federal Government employees. Public Pers. Manag. 1997, 26, 313-334. [CrossRef]

57. Guinot, J.; Chiva, R.; Roca-Puig, V. Interpersonal trust, stress and satisfaction at work: An empirical study. Pers. Rev. 2014, 43, 96-115. [CrossRef]

58. Hoffmann, T. The meanings of competency. J. Eur. Ind. Train. 1999, 23, 275-286. [CrossRef]

59. Gudanowska, A.E.; Alonso, J.P.; Törmänen, A. What competencies are needed in the production industry? The case of the Podlaskie Region. Eng. Manag. Prod. Serv. 2018, 10, 65-74. [CrossRef]

60. Athey, T.; Orth, M. Emerging competency methods for the future human resource management. Hum. Resour. Manag. 1999, 38, 215-226. [CrossRef]

61. Boam, R.; Sparrow, P. Designing and Achieving Competency; McGraw-Hill: London, UK, 1992.

62. Volpentesta, A.; Felicetti, A.M. Competence Mapping through Analysing Research Papers of a Scientific. Technol. Innov. Sustain. 2011, 33-44. [CrossRef]

63. Trinder, J.C. Competency Standards-A Measure of the Quality of a Workforce; Jun, C., Jie, J., Eds.; International Society for Photogrammetry and Remote Sensing/ISPRS Congress: Beijing, China, 2008; pp. 165-167. 
64. Boyatzis, R. The Competent Manager: A Model for Effective Performance; John Wiley \& Sons: New York, NY, USA, 1982; p. 20.

65. Dolot, A. Competency Assessment with the Help of Assessment and Development Center Methods. In Knowledge, Economy, Society: Strategies, Concepts and Instruments of Management; Oczkowska, R., Jaki, A., Mikuła, B., Eds.; Foundation of the Cracow University of Economics: Cracow, Poland, 2016; pp. $273-279$. ISBN 978-83-65173-73-7.

66. Hertle, C.; Tischa, M.; Kläsa, H.; Metternicha, J.; Abelea, E. Recording shop floor management competencies-A guideline for a systematic competency gap analysis. Procedia CIRP 2016, 57, 625-630. [CrossRef]

67. Christie, A.M.H.; Jordan, P.J.; Troth, A.C. Trust antecedents: Emotional intelligence and perceptions of others. Int. J. Organ. Anal. 2015, 23, 89-101. [CrossRef]

68. Sitkin, S.B.; Roth, N.L. Explaining the limited effectiveness of legalistic'remedies'for trust/distrust. Organ. Sci. 1993, 4, 367-392. [CrossRef]

69. Wasti, S.A.; Tan, H.H.; Erdil, S.E. Antecedents of trust across foci: A comparative study of Turkey and China. Manag. Organ. Rev. 2011, 7, 279-302. [CrossRef]

70. Gill, H.; Boies, K.; Finegan, J.E.; McNally, J. Antecedents of trust: Establishing a boundary condition for the relation between propensity to trust and intention to trust. J. Bus. Psychol. 2005, 19, 287-302. [CrossRef]

71. Snijders, C.; Keren, G. Do you trust? Whom do you trust? When do you trust? In Advances in Group Processes; Thye, S.R., Lawler, E.J., Macy, M.W., Walker, H.A., Eds.; JAI, Elsevier Science: Amsterdam, The Netherlands, 2001; pp. 129-160.

72. Sharif, K.J.; Kalafatis, S.P.; Samouel, P. Cognitive and behavioural determinants of trust in small and medium-sized enterprises. J. Small Bus. Enterp. Dev. 2005, 12, 409-421. [CrossRef]

73. Ingenhoff, D.; Sommer, K. Trust in companies and in CEOs: A comparative study of the main influences. J. Bus. Ethics 2010, 95, 339-355. [CrossRef]

74. Caldwell, C.; Clapham, S.E. Organisational trustworthiness: An international perspective. J. Bus. Ethics 2003, 47, 349-364. [CrossRef]

75. McKnight, D.H.; Chervany, N.L. What trust means in e-commerce customer relationships: An interdisciplinary conceptual typology. Int. J. Electron. Commer. 2002, 6, 35-59. [CrossRef]

76. Kee, H.W.; Knox, R.E. Conceptual and methodological considerations in the study of trust and suspicion. J. Confl. Resolut. 1970, 14, 357-366. [CrossRef]

77. Colquitt, J.A.; Rodell, J.B. Justice, trust, and trustworthiness: A longitudinal analysis integrating three theoretical perspectives. Acad. Manag. J. 2011, 54, 1183-1206. [CrossRef]

78. Tan, H.H.; Lim, A.K.H. Trust in coworkers and trust in organizations. J. Psychol. 2009, 143, 45-66. [CrossRef] [PubMed]

79. Ahmad, W.N.W.; Ali, N.M. Engendering Trust through Emotion in Designing Persuasive Application. In Advances in Visual Informatics. IVIC 2013. Lecture Notes in Computer Science; Zaman, H.B., Robinson, P., Olivier, P., Shih, T.K., Velastin, S., Eds.; Springer: Cham, Switzerland, 2013.

80. Dietz, G.; Den Hartog, D.N. Measuring trust inside organisations. Pers. Rev. 2006, 35, 557-588. [CrossRef]

81. Hodson, R. Organisational trustworthiness: Findings from the population of organizational ethnographies. Organ. Sci. 2004, 15, 432-445. [CrossRef]

82. Ozmen, Y.S. How employees define organisational trust: Analysing employee trust in organization. J. Glob. Responsib. 2018, 9, 21-40. [CrossRef]

83. Bouma, J.; Bulte, E.; Soest, D. Trust and cooperation: Social capital and community resource management. J. Environ. Econ. Manag. 2008, 56, 155-166. [CrossRef]

84. Parks, C.D.; Joireman, J.; Van Lange, P.A.M. Cooperation, Trust, and Antagonism: How Public Goods Are Promoted. Psychol. Sci. Public Interest 2013, 14, 119-165. [CrossRef] [PubMed]

85. Acedo, C.; Gomila, A. Trust and cooperation: A new experimental approach. Ann. N. Y. Acad. Sci. 2013, 1299, 77-83. [CrossRef] [PubMed]

86. Deck, C. An experimental analysis of cooperation and productivity in the trust game. Exp. Econ. 2009, 12, 1-11. [CrossRef]

87. Tuomela, R.; Tuomela, M. Cooperation and trust in group context. Mind Soc. 2005, 4, 49-84. [CrossRef]

88. Kanter, R.M. Confidence; Crown Buisness: New York, NY, USA, 2004; pp. 216-255.

89. Telecommunications Sector Turnover in Poland. Available online: https://www.statista.com/statistics/ 419630/telecommunications-sector-turnover-in-poland/ (accessed on 2 April 2018). 
90. Revenue of Top 20 European Telecommunication Operators. Available online: https:/ www.statista.com/ statistics /221386/revenue-of-top-20-european-telecommunication-operators/ (accessed on 3 April 2018).

91. ICT Employment. Available online: https://data.oecd.org/ict/ict-employment.htm (accessed on 2 April 2018).

92. Act of 16 July 2004-Telecommunications Law (Journal of Laws No. 171 Item 1800 with Subsequent Changes). Available online: http:/ / prawo.sejm.gov.pl/isap.nsf/DocDetails.xsp?id=WDU20041711800 (accessed on 5 January 2018).

93. Wu, J.J.; Chen, Y.H.; Chien, S.H.; Wu, W.K. Attachment relationship study of trust and trust transfer. J. Serv. Theory Pract. 2016, 26, 681-695. [CrossRef]

94. Joseph, E.E.; Winston, B.E. A correlation of servant leadership, leader trust, and organizational trust. Leadersh. Organ. Dev. J. 2005, 26, 6-22. [CrossRef]

95. Tzafrir, S.S.; Dolan, S.L. Trust Me: A Scale for Measuring Manager-Employee Trust, Management Research. J. Iberoam. Acad. Manag. 2004, 2, 115-132. [CrossRef]

96. Ermisch, J.; Gambetta, D.; Laurie, H.; Siedler, T.; Noah Uhrig, S.C. Measuring people's trust. J. R. Stat. Soc. A Stat. 2009, 172, 749-769. [CrossRef]

97. Oh, Y.; Park, J. New link between administrative reforms and job attitude: The role of interpersonal trust in peers as a mediator on organizational commitment. Int. Rev. Public Adm. 2011, 16, 65-87. [CrossRef]

98. Wu, W.L.; Lin, C.H.; Hsu, B.F.; Yeh, R.S. Interpersonal trust and knowledge sharing: Moderating effects of individual altruism and a social interaction environment. Soc. Behav. Pers. 2009, 37, 83-94. [CrossRef]

99. Moye, M.J.; Henkin, A.B. Exploring associations between employee empowerment and interpersonal trust in managers. J. Manag. Dev. 2006, 25, 101-117. [CrossRef]

100. Rotter, J.B. A new scale for the measurement of interpersonal trust. J. Pers. 1967, 35. [CrossRef]

101. Margerison, C. Team competencies. Team Perform. Manag. Int. J. 2001, 7, 117-122. [CrossRef]

102. Meyer, G.; Brünig, B.; Nyhuis, P. Employee competences in manufacturing companies-An expert survey. J. Manag. Dev. 2015, 34, 1004-1018. [CrossRef]

103. Waters, E.; Sroufe, L.A. Social competence as a developmental construct. Dev. Rev. 1983, 3, 79-97. [CrossRef]

104. Robotham, D.; Jubb, R. Competences: Measuring the unmeasurable. Manag. Dev. Rev. 1996, 9, $25-29$. [CrossRef]

105. Wiese, M.; Botha, E.; van Heerden, G. Social Relations Beyond Team-Based Learning. In Developments in Marketing Science: Proceedings of the Academy of Marketing Science; Kubacki, K., Ed.; Springer: New York, NY, USA, 2015.

106. Tierney, P. Work relations as a precursor to a psychological climate for change: The role of work group supervisors and peers. J. Organ. Chang. Manag. 1999, 12, 120-134. [CrossRef]

107. Forret, M.; Love, M.S. Employee justice perceptions and coworker relationships. Leadersh. Organ. Dev. J. 2008, 29, 248-260. [CrossRef]

108. Hornsey, M.J.; Hogg, M.A. Assimilation and diversity: An integrative model of subgroup relations. Pers. Soc. Psychol. Rev. 2000, 4, 143-156. [CrossRef]

109. Price, H.E. Employee Morale and Organizational Climate in Schools: The Importance of Affective Coworker Relationships, In Networks, Work and Inequality. In Research in the Sociology of Work; Mcdonald, S., Ed.; Emerald Group Publishing Limited: Bingley, UK, 2013; pp. 207-236.

110. Shih-Tse Wang, E. Moderators of the relationship between social bonding and organizational commitment. Manag. Serv. Qual. 2014, 24, 300-314. [CrossRef]

111. Graf, E.; Ausserhofer, D.; Schwendimann, R.; Zúñiga, F. Success factor emotional coworker engagement. Krankenpfl. Soins Infirm. 2015, 108, 20-21. [PubMed]

112. Nonose, K.; Kanno, T.; Furuta, K. Effects of metacognition in cooperation on team behaviors. Cognit. Technol. Work 2014, 16, 349-358. [CrossRef]

113. Sun, R.; Qi, D. Learning Team Cooperation. ICONIP Lecture Notes in Computer Science. In Neural Information Processing; Pal, N.R., Kasabov, N., Mud, R.K., Pal, S., Parui, S.K., Eds.; Springer: Berlin/Heidelberg, Germany, 2004.

114. Grossman, R.; Rosch, Z.; Mazer, D.; Salas, E. What Matters for Team Cohesion Measurement? A Synthesis. In Team Cohesion: Advances in Psychological Theory, Methods and Practice (Research on Managing Groups and Teams); Salas, E., Vessey, W.B., Estrada, A.X., Eds.; Emerald Group Publishing Limited: Bingley, UK, 2015; ISBN 978-1-78560-283-2. 
115. Knott, C.C.; Geyer, A.; Sidman, J.; Wiese, E. Multi-Modal Measurement Approach to Team Cohesion. In Foundations of Augmented Cognition. Directing the Future of Adaptive Systems, Lecture Notes in Computer Science; Schmorrow, D.D., Fidopiastis, C.M., Eds.; Springer: New York, NY, USA, 2011; Volume 6780, pp. 318-324. ISBN 978-3-642-21852-1.

116. Team Cohesion. Management Accounting \& Control Scales Handbook 2007; Springer Science \& Business Media: Berlin, Germany, 2002.

117. Mayer, R.C.; Gavin, M.B. Trust in management and performance: Who minds the shop while the employees watch the boss? Acad. Manag. J. 2005, 48, 874-888. [CrossRef]

118. Mayer, R.C.; Davis, J.H. The effect of the performance appraisal system on trust for management: A field quasi-experiment. J. Appl. Psychol. 1999, 84, 123-136. [CrossRef]

119. Poon, J.M. Trust-in-supervisor and helping coworkers: Moderating effect of perceived politics. J. Manag. Psychol. 2006, 21, 518-532. [CrossRef]

120. Naim, M.F.; Lenka, U. Linking knowledge sharing, competency development, and affective commitment: Evidence from Indian Gen Y employees. J. Knowl. Manag. 2017, 21, 885-906. [CrossRef]

121. Leicher, V.; Mulder, R.H. Team learning, team performance and safe team climate in elder care nursing. Team Perform. Manag. 2016, 22, 399-414. [CrossRef]

122. Tan, S.; Tambyah, S. Generalized Trust and Trust in Institutions in Confucian Asia. Soc. Indic. Res. 2011, 103, 357-377. [CrossRef]

123. Macy, M.W.; Sato, Y. Trust, cooperation, and market formation in the U.S. and Japan. Proc. Natl. Acad. Sci. USA 2002, 99 (Suppl. 3), 7214-7220. [CrossRef] [PubMed]

124. Six, F.; Sorge, A. Creating a High-Trust Organization: An Exploration into Organizational Policies that Stimulate Interpersonal Trust Building. J. Manag. Stud. 2008, 45, 857-884. [CrossRef]

125. So, M.W.C.; Sculli, D. The role of trust, quality, value and risk in conducting e-business. Ind. Manag. Data Syst. 2002, 102, 503-512. [CrossRef]

(C) 2018 by the authors. Licensee MDPI, Basel, Switzerland. This article is an open access article distributed under the terms and conditions of the Creative Commons Attribution (CC BY) license (http:/ / creativecommons.org/licenses/by/4.0/). 